\title{
PERLAKUAN AKUNTANSI KREDIT BERMASALAH SETELAH PSAK NO.31 EFEKTIF DICABUT PADA PT. BANK TABUNGAN NEGARA
}

\author{
Muhammad Rizqi Rafsanjani ${ }^{1}$ \\ mrizqirafsanjani@yahoo.com \\ $\underline{\text { Ngadirin Setiawan }^{2}}$
}

\section{Fakultas Ekonomi Universitas Negeri Yogyakarta}

\begin{abstract}
ABSTRAK
Penelitian ini merupakan penelitian deskriptif kualitatif. Penelitian ini bertujuan untuk mengetahui perlakuan akuntansi kredit bermasalah pada PT. Bank Tabungan Negara (Persero) Tbk. setelah PSAK No. 31 efektif dicabut dan kesesuaiannya dengan PSAK No. 55 (revisi 2011), PSAK No. 50 (revisi 2010) dan PSAK No. 60 (revisi 2010).Metode pengumpulan data yang digunakan dalam penelitian ini adalah penelitian kepustakaan dan penelitian lapangan. Metode analisis data yang digunakan adalah analisis deskriptif. Berdasarkan hasil penelitian menunjukkan setelah efektif dicabutnya PSAK No. 31 pada 1 Januari 2010 tentang Akuntansi Perbankan maka dalam perlakuan akuntansi instrumen keuangan aset, ekuitas, dan liabilitas pada PT. BTN (Persero) Tbk. menggunakan PSAK No. 50 (revisi 2010), PSAK No. 55 (revisi 2011) dan PSAK No. 60 (revisi 2010). Praktik perlakuan kredit bermasalah dan pendapatan bunga pada PT. Bank Tabungan Negara (Persero) Tbk. telah sesuai dengan PSAK No. 55 (revisi 2011) dan PSAK No. 60 (revisi 2010).Perlakuan untuk penyisihan kerugian penurunan nilai, restrukturisasi kredit dan penghapusbukuan kredit sudah sesuai dengan PSAK No. 55 (revisi 2011).Khusus untuk penyajian kredit bermasalah dan pendapatan bunga tidak diatur dalam PSAK No.50 (revisi 2010) karena PSAK tersebut hanya mengatur penyajian ekuitas dan liabiitas.
\end{abstract}

Kata Kunci: Pernyataan Standar Akuntansi Keuangan (PSAK), Kredit Bermasalah

\section{ABSTRACT}

This research is a qualitative research which aim to investigate the treatment of nonperforming loan accounting in PT. Bank Tabungan Negara (Ltd,) after PSAK No. 31 is effectively taken and compatible with PSAK No. 55 (revision 2011), PSAK No. 50 (revision 2010) and PSAK No. 60 (revision 2010). The method that is used for collecting data in the research is library research and field research. The analysis data that is used is descriptive analysis. According to result of this thesis shows that after PSAK No. 31 on $1^{\text {st }}$ of January 2010 about Banking Accounting take effectively so in the treatment in instrument accounting of finance asset, equity, and liability in PT. BTN (ltd,) uses PSAK No. 50 (revision 2010), PSAK No. 55 (revision 2011) and PSAK No. 60 (revision 2010). The practice of treatment of nonperforming loan and income of interest in PT. Bank Tabungan Negara (Ltd,) have appropriated with No. 55 (revision 2011) and PSAK No. 60 (revision 2010). The treatment for elimination disadvantages of decreasing values,

\footnotetext{
${ }^{1}$ Alumni Prodi Akuntansi Fakultas Ekonomi Universitas Negeri Yogyakarta

${ }^{2}$ Staf Pengajar Jurusan P. Akuntansi Fakultas Ekononi Universitas Negeri Yogyakarta
} 
restructurisation credit and eraser credit book have appropriated with PSAK No. 55 (revision 2011). Especially for service trouble credits and income of interest don't manage in PSAK No. 50 (revision 2010) because the PSAK just manage the service of equity and liability.

Key Words: Pernyataan Standar Akuntansi Keuangan (PSAK), Nonperforming Loan

\section{A. PENDAHULUAN}

\section{Latar Belakang Masalah}

Aktivitas bisnis merupakan fenomena yang sangat komplek karena mencakup berbagai bidang baik hukum, ekonomi, dan politik.Aktivitas bisnis dalam kehidupan masyarakat sering kali tidak bisa terlepas dari peran bank selaku pemberi layanan perbankan bagi masyarakat.Bank dalam pembicaraan sehari-hari di tengah masyarakat dikenal sebagai lembaga keuangan yang kegiatan utamanya adalah menerima simpanan giro, tabungan dan deposito.Bank selain menerima simpanan giro, tabungan dan deposito dalam perkembangannya bank juga dikenal sebagai tempat untuk meminjam uang (kredit) bagi masyarakat yang membutuhkannya.Bank juga dikenal sebagi tempat menukar uang, memindahkan uang atau menerima segala macam bentuk pembayaran dan setoran seperti pembayaran listrik, telepon, air, pajak, uang kuliah, dan pembayaran lainnya.

Menurut Undang-undang Nomor 10 Tahun 1998 yang merupakan perubahan atas Undang-undang Nomor 7 Tahun 1992 tentang Perbankan menyebutkan bahwa fungsi utama perbankan Indonesia adalah sebagai penghimpun dan penyalur dana masyarakat yang bertujuan menunjang pelaksanaan pembangunan nasional ke arah peningkatan kesejahteraan rakyat banyak. Bank berfungsi untuk menjembatani kedua kelompok masyarakat yang saling membutuhkan. Masyarakat yang memiliki kelebihan dana dapat menyimpan uang mereka dalam bentuk tabungan, deposito atau giro pada bank, sedangkan masyarakat yang membutuhkan dana untuk modal usaha atau untuk memenuhi kebutuhan lainnya dapat memperoleh pinjaman dalam bentuk kredit yang disalurkan oleh bank. Fungsi perbankan tidak hanya sekedar sebagai wadah penghimpun dan penyalur dana masyarakat atau perantara penabung dan investor, tetapi fungsinya akan diarahkan kepada peningkatan taraf hidup orang banyak, agar masyarakat menjadi lebih baik dan lebih sejahtera daripada sebelumnya.

Perbankan mempunyai berbagai macam bentuk usaha bank yang salah satunya adalah pemberian kredit.Perkreditan merupakan usaha utama perbankan, dimana rata- 
rata jumlah harta bank di banyak negara ekonomi maju dan berkembang yang terikat dalam bentuk kredit.Pendapatan terbesar bank berasal dari bunga, imbalan atau pembagian hasil usaha atas kredit yang disalurkan.Semakin banyak jumlah kredit yang disalurkan berarti potensi pendapatan semakin besar. Akan tetapi, dalam pelaksanaannya tidak semua dana yang dihimpun dari masyarakat bisa disalurkan dengan baik sesuai dengan tolak ukur yang telah ditetapkan dan penyaluran kredit kepada masyarakat biasanya mengalami hambatan dalam hal pengembalian pinjaman kepada pihak bank dan nyaris semua bank yang beroperasi di Indonesia mengalami kredit bermasalah (nonperforming loan).Risiko yang ditimbulkan atas kredit bermasalah yakni tidak terbayarnya kembali kredit yang diberikan baik sebagian maupun seluruhnya.

Salah satu ruang lingkup kegiatan PT. Bank Tabungan Negara (Persero) Tbk. adalah memberikan fasilitas kredit kepada sektor usaha, dimana kredit tersebut bersumber dari dana yang dihimpun dari giro, deposito, dan tabungan. Dalam menjalankan fungsinya sebagai bank umum, kebijaksanaan perkreditan PT. Bank Tabungan Negara (Persero) Tbk. senantiasa diarahkan pada semua sektor usaha dengan pemberian kredit jangka pendek dan menengah serta prioritas sektor-sektor yang dapat mendorong pertumbuhan ekonomi. Untuk tujuan perkreditan tersebut, PT. Bank Tabungan Negara (Persero) Tbk. telah ikut serta secara aktif dalam menyalurkan kredit kepada masyarakat atau sektor usaha yang pembiayaannya bersumber dari dana yang dihimpun dari masyarakat itu sendiri.

PT. Bank Tabungan Negara (Persero) Tbk. adalah salah satu bank yang dimiliki oleh Badan Usaha Milik Negara yang mengalami permasalahan kredit bermasalah (nonperforming loan). Jumlah kredit bermasalah pada PT. Bank Tabungan Negara (Persero) Tbk. tahun 2011 mengalami kenaikan jika dibandingkan dengan tahun 2010 dari Rp.1.543.007 naik menjadi Rp.1.600.345. Akan tetapi jika dilihat dari nilai rasio nonperforming loan (NPL) pada PT. Bank Tabungan Negara (Persero) nilainya mengalami penurunan dari $2,70 \%$ menjadi 2,32\%. Nilai rasio nonperforming loantersebut berada di batas aman karena nilainya di bawah 5\%sesuai dengan ketetapan Peraturan Bank Indonesia yang menetapkan standar rasio nonperforming loan di bawahdari 5\%. Namun bukan berarti dengan nilai rasio NPL yang berada di bawah dari 5\% dapat dengan mudah meningkatkan profitabilitas bank yang diharapkan karena semakin besar kredit bermasalah yang dihadapi, maka semakin menurun pula tingkat kesehatan bank tersebut (menurunnya profitabilitas yang 


\section{JURNAL NOMINAL / VOLUME II NOMOR I / TAHUN 2013}

diharapkan). Hal ini mempengaruhi kepercayaaan terhadap nasabah. Semakin besar jumlah kredit bermasalah, maka semakin besar pula jumlah cadangan yang harus disediakan dan semakin besar pula tanggungan bank untuk mengadakan dana cadangan tersebut karena kerugian bank akan mengurangi modal sendiri.

Di Indonesia,prinsip akuntansi yang berlaku adalah Standar Akuntansi Keuangan (SAK) yang dikeluarkan oleh Ikatan Akuntan Indonesia (IAI). Sebelum tanggal 1 Januari 2010, industri perbankan merupakan suatu perusahaan yang memiliki suatu karakteritik tersendiri yang dibuat suatu standar khusus untuk pelaporan keuangan yang dituangkan dalam Pernyataan Standar Akuntansi Keuangan No. 31 (revisi 2000) mengenai perbankan. PSAK No. 31 tentang Akuntansi Perbankan yang telah diterapkan oleh bank dalam mempersiapkan laporan keuangan tahun 2009 telah dicabut efektif tanggal 1 Januari 2010, berkaitan dengan penerapan PSAK No. 55 (Revisi 2006) tentang pengakuan dan pengukuran instrumen keuangan, dan PSAK No.50 (Revisi 2006) tentang penyajian dan pengungkapan instrumen keuangan efektif berlaku pada 1 Januari 2010. Akan tetapi sejak 1 Januari 2012 bank mulai menerapkan PSAK No. 50 (Revisi 2010) tentang Peyajian Instrumen Keuangan, PSAK No. 55 (Revisi 2011) tentang Pengakuan dan Pengukuran Instrumen Keuangan dan PSAK No. 60 tentang Pengungkapan Instrumen Keuangan. Ketiga PSAK tersebut menggantikan PSAK No. 55 (Revisi 2006) dan PSAK No. 50 (Revisi 2006) efektif sejak 1 Januari 2012.

PSAK No. 50 (revisi 2010) berisi persyaratan penyajian dari instrumen keuangan dan pengidentifikasian informasi yang harus diungkapkan.Persyaratan penyajian tersebut diterapkan terhadap klasifikasi instrumen keuangan, dari perspektif penerbit dalam aset keuangan, kewajiban keuangan dan instrumen ekuitas, pengklasifikasian yang terkait dengan suku bunga, dividen, kerugian dan keuntungan, dan keadaan dimana aset keuangan dan kewajiban saling hapus. PSAK ini mensyaratkan pengungkapan, antara lain informasi mengenai faktor yang mempengaruhi jumlah, waktu dan tingkat kepastian arus kas masa depan suatu entitas terkait dengan instrument keuangan dan kebijakan akuntansi yang diterapkan untuk instrumen tersebut.

PSAK No.55 (Revisi 2011) menetapkan prinsip untuk pengakuan dan pengukuran aset keuangan, kewajiban keuangan dan kontrak pembelian atau penjualan item non keuangan.PSAK ini memberikan definisi dan karakteristik derivativ, 
kategori-kategori dari masing-masing instrumen keuangan, pengakuan dan pengukuran, akuntansi lindung nilai dan penetapan dari hubungan lindung nilai.

PSAK No.60 mensyaratkan pengungkapan signifikan atas masing-masing instrumen keuangan untuk posisi keuangan dan kinerjanya, serta sifat dan tingkat risiko yang timbul dari instrumen keuangan yang dihadapi oleh PT. Bank Tabungan Negara (Persero) Tbk. selama periode berjalan dan pada akhir periode pelaporan, dan bagaimana PT. Bank Tabungan Negara (Persero) Tbk. mengelola risiko tersebut.

Ketiga standar tersebut merupakan standar akuntansi yang mengacu pada International Accounting Standard (IAS) 39 mengenai Recognition and Measurement of Financial Instruments dan IAS 32 mengenai Presentation and Disclosures of Financial Instruments.Dengan demikian ketiga standar tersebut telah sesuai dengan International Financial Reporting System (IFRS) yang sebelumya telah diterapkan oleh perbankan internasional.Hal ini mengakibatkan sejak tanggal 1 Januari 2010 pula Pernyataan Standar Akuntansi Keuangan No.31 efektif dicabut.Keputusan ini diambil agar perbankan Indonesia bisa diakui secara global untuk dapat bersaing dan menarik investor secara global. Berdasarkan uraian di atas, maka penulis memilih judul "Perlakuan Akuntansi Kredit Bermasalah (Nonperforming Loan) Setelah Pernyataan Standar Akuntansi Keuangan No. 31 Efektif Dicabut pada PT. Bank Tabungan Negara (Persero) Tbk.

\section{B. KAJIAN LITERATUR}

\section{Pernyataan Standar Akuntansi Keuangan}

\section{a. Pengertian Standar Akuntansi Keuangan}

Pernyataan Standar Akuntansi Keuangan merupakan aturan dan pedoman bagi manajemen dalam menyusun laporan keuangan.Dengan adanya Standar Akuntansi yang baik, laporan keuangan menjadi lebih berguna, dapat diperbandingkan, tidak menyesatkan dan dapat menciptakan transparasi perusahaan.

Menurut Financial Accounting Standard Board(FASB) medefinisikan Standar Akuntansi adalah metode yang seragam untuk menyajikan informasi, sehingga laporan keuangan dari berbagai perusahaan yang berbeda dapat dibandingkan dengan lebih mudah kumpulan konsep, standar, prosedur, metode, konvensi, kebiasaan dan praktik yang dipilih dan dianggap berterima umum.Standar akuntansi keuangan (SAK) yang dibuat oleh IAI selalu mengikuti 
perkembangan International Accounting Standards Committee (IASC).Selain mengikuti IAS, SAK juga mempertimbangkan berbagai faktor lingkungan usaha yang ada di Indonesia sehingga di harapkan SAK yang diterbitkan dapat sesuai dengan tuntutan kebutuhan dunia usaha di Indonesia juga sejalan dengan standar akuntasi internasional.

\section{b. Pernyataan Standar Akuntansi Keuangan No. 60 Instrumen Keuangan:}

\section{Pengungkapan}

\section{1) Kategori Aset Keuangan dan Liabilitas Keuangan}

Nilai tercatat untuk setiap kategori berikut, sebagaimana didefinisikan dalam PSAK 55 (revisi 2006) diungkapkan dalam laporan posisi keuangan atau catatan atas laporan keuangan:

a) Aset keuangan yang diukur pada nilai wajar melalui laporan laba rugi.

b) Investasi dimiliki hingga jatuh tempo.

c) Pinjaman yang diberikan dan piutang.

d) Liabilitas keuangan yang diukur pada nilai wajar melalui laporan laba rugi.

\section{2) Penyisihan Kerugian Kredit}

Ketika aset keuangan mengalami penurunan nilai karena kerugian kredit dan entitas mencatat penurunan nilai dalam pos terpisah (misalnya pos penyisihan digunakan untuk mencatat penurunan nilai individual atau pos serupa yang digunakan untuk mencatat penurunan nilai kolektif atas aset keuangan) daripada secara langsung mengurangi nilai tercatat aset keuangan, maka entitas mengungkapkan suatu rekonsiliasi perubahan pada akun tersebut selama periode untuk setiap kelompok aset keuangan.

\section{3) Pos-pos Penghasilan, Beban, Keuntungan atau Kerugian}

Entitas mengungkapkan pos penghasilan, beban, keuntungan atau kerugian berikut ini pada laporan laba rugi komprehensif atau catatan atas laporan keuangan.

a) Laba atau rugi neto pada.

(1) Aset keuangan atau liabilitas keuangan yang diukur pada nilai wajar melalui laporan laba-rugi, yang menunjukkan secara terpisah aset keuangan atau liabilitas keuangan yang telah ditetapkan untuk diukur pada nilai wajar melalui laporan laba rugi pada saat pengakuan awal, dan aset keuangan atau laibilitas keuangan yang dikategorikan sebagai dimiliki untuk diperdagangkan sesuai PSAK 55 (revisi 2006). 
(2) Aset keuangan tersedia dijual, yang menunjukkan secara terpisah jumlah keuntungan atau kerugian yang diakui pada pendapatan komprehensif lain selama periode, dan jumlah yang dipindahkan dari ekuitas ke dalam laporan laba rugi tersebut.

(3) Investasi dimiliki hingga jatuh tempo.

(4) Pinjaman yang diberikan dan piutang.

(5) Liabilitas keuangan yang diukur pada biaya perolehan diamortisasi.

b) Total pendapatan bunga dan total beban bunga (dihitung dengan menggunakan metode suku bunga efektif) untuk aset keuangan atau liabilitas keuangan yang tidak diukur pada nilai wajar melalui laporan laba rugi.

c) Pendapatan bunga dari aset keuangan yang mengalami penurunan nilai yang diakui sesuai PA 109 PSAK 55.

d) Jumlah kerugian penurunan nilai untuk setiap kelompok aset keuangan

\section{4) Pengungkapan Lain}

Sesuai dengan PSAK 1 (revisi 2009) tentang penyajian laporan keuangan paragraf 114, entitas mengungkapkan dalam ikhtisar kebijakan akuntansi yang signifikan, dasar pengukuran yang digunakan dalam menyusun laporan keuangan dan kebijakan akuntansi lain yang relevan untuk pemahaman suatu laporan keuangan.

\section{5) NilaiWajar}

Setiap kelompok aset keuangan dan kewajiban keuangan, entitas harus mengungkapkan nilai wajar setiap kelompok asset dan kewajiban tersebut dengan cara yang memungkinkan untuk dapat diperbandingkan dengan nilai tercatat dalam neraca. (PSAK55 (revisi2006) memberikan pedoman penentuan nilai wajar).

Dalam pengungkapan nilai wajar, entitas mengelompokkan aset keuangan dan liabilitas keuangan dalam kelompok-kelompok, namun saling hapus di antara mereka sepanjang jumlah tercatatnya saling hapus dalam laporan keuangan.

Entitas mengungkapkan untuk setiap kelompok instrumen keuangan, metode dan, ketika teknik penilaian digunakan, asumsi yang diterapkan dalam menentukan nilai wajar untuk setiap kelompok aset keuangan atau liabilitas keuangan. 


\section{c. Pernyataan Standar Akuntansi Keuangan No. 55 (Revisi 2011) Instrumen Keuangan: Pengakuan dan Pengukuran}

Tujuan pernyataan ini adalah untuk mengatur prinsip-prinsip dasar pengakuan dan pengukuran asset keuangan, kewajiban keuangan, dan kontrak pembelian atau penjualan items non keuangan.

\section{1) Pengakuan Awal}

a) Aset keuangan dan liabilitas pada awalnya diukur pada nilai wajarnya. Dalam hal aset keuangan atau liabilitas keuangan tidak diukur pada nilai wajarnya melalui laporan laba rugi, nilai wajarnya tersebut ditambah biaya transaksi yang dapat diatribusikan secara langsung. Pengukuran aset keuangan dan liabilitas keuangan setelah pengakuan awal tergantung klasifikasinya. Nilai wajar aset keuangan pada saat pengakuan awal biasanya sama dengan harga transaksinya yaitu nilai wajar pembayaran yang diserahkan atau diterima.

\section{2) Pengukuran setelah Pengakuan Awal}

a) Aset keuangan dalam kelompok tersedia untuk dijual dan aset keuangan dan liabilitas keuangan yang diukur pada nilai wajar melalui laporan laba rugi diukur pada nilai wajarnya.

b) Kredit yang diberikan, piutang serta investasi dimiliki yang hingga jatuh tempo dan liabilitas keuangan yang diukur pada biaya perolehan diamortisasi diukur pada biaya perolehan diamortisasi dengan menggunakan metode suku bunga efektif.

\section{3) Penghentian Pengakuan}

a) Aset keuangan dihentikan pengakuannya jika hak kontraktual atas arus kas yang berasal dari aset keuangan tersebut berakhir.

b) Pinjaman yang diberikan atau aset keuangan lain dihapusbukukan ketika tidak terdapat prospek yang realistis mengenai pengembalian kredit dalam waktu dekat atau hubungan normal antara bank dan debitur telah berakhir. Kredit yang tidak dapat dilunasi dihapusbukukan dengan mendebit penyisihan kerugian penurunan nilai. Penerimaan kemudian atas kredit yang telah dihapusbukukan sebelumnya, jika pada periode berjalan dikreditkan ke dalam akun penyisihan kerugian penurunan nilai atas kredit yang diberikan di laporan posisi keuangan, sedangkan jika setelah tanggal 
laporan posisi keuangan dikreditkan sebagai pendapatan operasional lainnya.

\section{4) Pengakuan Pendapatan dan Beban}

a) Aset tersedia untuk dijual serta aset keuangan dan liabilitas keuangan yang dicatat berdasarkan biaya perolehan diamortisasi, pendapatan dan beban bunga diakui pada laporan laba rugi dengan menggunakan metode suku bunga efektif.

b) Keuntungan dan kerugian yang belum terealisasi yang timbul dari perubahan nilai wajar aset keuangan dan liabilitas keuangan yang diukur pada nilai wajar melalui laporan laba rugi diakui pada laporan laba rugi.

c) Pada saat aset keuangan dihentikan pengakuannya atau mengalami penurunan nilai, keuntungan atau kerugian kumulatif yang sebelumnya diakui dalam laporan laba rugi komprehensif harus diakui pada laporan laba rugi.

5) Aset Keuangan yang Dicatat Berdasarkan Biaya Perolehan Diamortisasi

Jika terdapat bukti obyektif bahwa kerugian penurunan nilai telah terjadi atas pinjaman yang diberikan dan piutang atau investasi dimiliki hingga jatuh tempo yang dicatat pada biaya perolehan diamortisasi, maka jumlah kerugian tersebut diukur sebagai selisih antara nilai tercatat aset dengan nilai kini estimasi arus kas masa datang (tidak termasuk kerugian kredit di masa datang yang belum terjadi) yang didiskontokan menggunakan suku bunga efektif awal dari aset tersebut (yaitu suku bunga efektif yang dihitung saat pengakuan awal). Nilai tercatat aset tersebut dikurangi baik secara langsung maupun menggunakan pos cadangan.Jumlah kerugian yang terjadi diakui pada laporan laba-rugi.

\section{6) Pengukuran Biaya Diamortisasi}

Biaya perolehan diamortisasi dari aset keuangan atau liabilitas keuangan adalah jumlah aset keuangan atau liabilitas keuangan yang diukur pada saat pengakuan awal dikurangi pembayaran pokok pinjaman, ditambah atau dikurangi amortisasi kumulatif menggunakan metode suku bunga efektif yang dihitung dari selisih antara nilai pengakuan awal dan nilai jatuh temponya, dan dikurangi penurunan nilai. 


\section{7) Pengukuran Nilai Wajar}

Nilai wajar adalah nilai dimana suatu asset dapat dipertukarkan, atau suatu liabilitas dapat diselesaikan, diantara para pihak yang memahami dan berkeinginan untuk melakukan transaksi yang wajar pada tanggal pengukuran.

\section{8) Metode Suku Bunga Efektif}

Metode yang digunakan untuk menghitung biaya perolehan diamortisasi dari aset keuangan atau liabilitas keuangan (atau kelompok aset keuangan atau liabilitas keuangan) dan metode untuk mengalokasikan pendapatan bunga atau beban bunga selama periode relevan. Suku bunga efektif adalah suku bunga yang secara tepat mendiskontokan estimasi pembayaran atau penerimaan kas di masa depan selama perkiraan umur dari instrument keuangan, atau jika lebih tepat, digunakan periode lebih singkat untuk memperoleh nilai tercatat bersih dari aset keuangan atau liabilitas keuangan.

\section{Kredit Bermasalah}

\section{a. Pengertian Kredit Bermasalah (Nonperforming Loan)}

Kredit bermasalah adalah dimana debitur mengingkari janji mereka membayar bunga dan atau kredit induk yang telah jatuh tempo, sehingga terjadi keterlambatan pembayaran atau sama sekali tidak ada pembayaran (Siswanto, 1997: 11).

Menurut Suhardjono melalui Ema (2009: 21) Kredit bermasalah adalah suatu keadaan dimana nasabah sudah tidak sanggup membayar sebagian atau seluruh kewajibannya kepada bank seperti yang telah diperjanjikan dalam perjanjian kredit.

Menurut Ikatan Akuntan Indonesia (2007: 31.5) dalam PSAK No.31 (2000), kredit bermasalah (nonperforming loan) pada umumnya merupakan kredit yang pembayaran angsuran pokoknya dan atau bunganya telah lewat 90 hari atau lebih setelah jatuh tempo, atau kredit yang pembayarannya secara tepat waktu sangat diragukan. Kredit nonperforming terdiri atas kredit yang digolongkan kurang lancar, diragukan, macet.

Jadi dapat disimpulkan, kredit bermasalah adalah suatu keadaan dimana nasabah sudah tidak sanggup membayar sebagian atas seluruh kewajibannya kepada bank seperti yang telah diperjanjikan dan dapat menimbulkan kerugian potensial kepada bank. 


\section{b. Penilaian Kredit Bermasalah (Nonperforming Loan)}

Pada penelitian kali ini rasio keuangan yang digunakan sebagai tolak ukur terhadap nilai suatu risiko kredit adalah rasio nonperforming loan. Rasio nonperforming loan merupakan rasio kredit yang menunjukan jumlah kredit yang disalurkan yang mengalami masalah tentang kegagalan pihak debitur untuk memenuhi kewajibannya membayar angsuran (cicilan) pokok beserta bunga yang telah disepakati (Lukman Dendawijaya 2003: 85).

Bank Indonesia (BI) melalui Peraturan Bank Indonesia (PBI) menetapkan bahwa standar rasio kredit bermasalah (NPL) adalah kurang dari 5\% (PBI Nomor: $3 / 25 / 2001$ ). Secara matematis NPL dapat dirumukan sebagai berikut (Taswan, 2008:59):

NPL $=\quad$ Jumlah Kredit Bermasalah

Total Kredit X $100 \%$

Keterangan:

Kredit Bermasalah $=$ Kurang Lancar + Diragukan + Macet

Total Kredit = Lancar + Dalam Perhatian Khusus + Kurang Lancar + Diragukan + Macet

Menurut Kasmir (2008: 123) untuk menentukan berkualitas atautidaknya suatu kredit perlu diberikan ukuran-ukuran tertentu. Bank Indonesia menggolongkan kualitas kredit menurut ketentuan sebagai berikut.

a) Lancar (pas)

Suatu kredit dapat dikatakan lancar apabila:

1) Pembayaran angsuran pokok dan atau bunga tepat waktu

2) Memiliki mutasi rekening yang aktif

3) Bagian dari kredit yang dijamin dengan agunan tunai (cash collateral).

b) Dalam Perhatian Khusus (special mention)

Dikatakan dalam perhatian khusus apabila memenuhi kriteria di antara lain:

1) Terdapat tunggakan pembayaran angsuran pokok dan atau bunga yang belum melampui dari 90 hari

2) Kadang-kadang terjadi cerukan

3) Jarang terjadi pelanggaran terhadap kontrak yang diperjanjikan

4) Mutasi rekening reklatif aktif 
5) Didukung dengan pinjaman baru.

c) Kurang Lancar (substandard)

Dikatakan kurang lancar apabila memenuhi kriteria di antaranya:

1) Terdapat tunggakan pembayaran angsuran pokok dan atau bunga yang telah melampui 90 hari

2) Sering terjadi cerukan

3) Terjadi pelanggaran terhadap kontrak yang diperjanjikan lebih dari 90 hari

4) Frekuensi mutasi rekening reklatif rendah

5) Terdapat indikasi masalah keuangan yang dihadapi debitur

6) Dokumen pinjaman yang lemah.

d) Diragukan (doubtful)

Dikatakan diragukan apabila memenuhi kriteria di antaranya:

1) Terdapat tunggakan pembayaran angsuran pokok dan atau bunga yang telah melampaui 180 hari

2) Terjadi cerukan yang besifat permanen

3) Terjadi wanprestasi lebih dari 180 hari

4) Terjadi kapitalisasi bunga

5) Dokumen hukum yang lemah, baik untuk perjanjian kredit maupun peningkatan jaminan.

e) Macet (loss)

Dikatakan macet apabila memenuhi kriteria antara lain:

1) Terdapat tunggakan pembayaran angsuran pokok dan atau bunga yang telah melampaui 270 hari

2) Kerugian operasional ditutup dengan pinjaman baru

3) Dari segi hukum dan kondisi pasar, jaminan tidak dapat dicairkan pada nilai yang wajar.

\section{Kerangka Berfikir}

Kredit bermasalah adalah dimana debitur mengingkari janji mereka membayar bunga dan atau kredit induk yang telah jatuh tempo, sehingga terjadi keterlambatan pembayaran atau sama sekali tidak ada pembayaran. Di dalam Peraturan Standar Akuntansi Keuangan (PSAK) perlakuan tentang kredit bermasalah ini diatur dalam PSAK No. 31 tentang Akuntansi Perbankan.PSAKNo.31adalah standar akuntansi khusus atau pedoman yang mengatur tentang akuntansi perbankan yang diduga 
merupakan salah satu factor pendorong perkembangan dunia perbankan. Penerapan PSAKNo. 31 yaitu tentang penyusunan laporan keuangan atau pelaporan keuangan, penerapan aktiva, penerapan kewajiban, penerapan ekuitas dan penerapan pendapatan dan beban dimaksudkan agar kualitas informasi laporan keuangan yang disajikan akan lebih terjaga akun tabilitasnya serta lebih handal dan relevan. Selain itu diharapkan informasi keuangan yang disajikan tidak menyesatkan penggunanya dan akan mendorong ketepatan dalam pengambilan keputusan yang nantinya berpengaruh terhadap perkembangan perbankan tersebut. Jadi apabila sebuah bank dalam praktik akuntansinya tidak disesuaikan dengan standar akuntansi atau PSAK No.31 maka laporan keuangan yang disajikan juga akan menurunkan tingkat relevansinya dan tidak dapat diperbandingkan serta diragukan tingkat keandalannya.

Namun karena dampak dari konvergensi ke standar akuntansi internasional (International Financial Reporting Standard atau IFRS) mengakibatkan perlunya pencabutan terhadap Pernyataan Standar Akuntansi Keuangan No. 31 Revisi 2000 Akuntansi Perbankan, sebagai gantinya bank diwajibkan menerapkan Pernyataan PSAK No.50 (revisi 2010) Instrumen keuangan: Penyajian, PSAK No. 55(revisi 2011) Instrumen keuangan: Pengakuan dan Pengukuran; dan PSAK No. 60 Instrumen Keuangan: Pengungkapan. Dengan diberlakukannya ketiga PSAK tersebut tentu akan mengakibatkan perubahan dalam memperlakukan kredit bermasalah, oleh karena itu perlu dilakukan sosialisasi dan pengawasan mengingat konvergensi ini pada awalnya baru dilakukan pada sektor perbankan di Indonesia.

\section{Pertanyaan Penelitian}

a. Bagaimana pengakuan, pengukuran, penyajian dan pengungkapan kredit bermasalah pada PT. Bank Tabungan Negara (Persero) setelah PSAK No.31 efektif dicabut?

b. Bagaimana pengakuan, pengukuran, penyajian dan pengungkapan pendapatan bunga yang ditimbulkan dari pemberian kredit pada PT. Bank Tabungan Negara (Persero) setelah PSAK No.31 efektif dicabut?

c. Bagaimana perlakuan penyisihan kerugian penurunan nilai pada PT. Bank Tabungan Negara (Persero) setelah PSAK No.31 efektif dicabut?

d. Bagaimana perlakuan pinjaman yang direstrukturisasi pada PT. Bank Tabungan Negara (Persero) setelah PSAK No.31 efektif dicabut?

e. Bagaimana penghapusbukuan kredit pada PT. Bank Tabungan Negara (Persero) setelah PSAK No.31 efektif dicabut? 


\section{METODE PENELITIAN}

\section{Jenis Penelitian}

Penelitian ini termasuk penelitian deskriptif kualitatif yaitu penelitian yang berisi paparan dengan tidak melibatkan kalkulasi angka (Mudrajad, 2003: 21). Dengan kata lain penelitian ini tidak didasarkan pada perhitungan statistik yang berbentuk kuantitatif tetapi dalam pernyataan dan uraian yang selanjutnya akan disusun secara sistematis.

\section{Subjek dan Objek Penelitian}

Subjekpenelitianadalah Kepala Bagian Akuntansi dan Kepala Bagian Kredit pada PT. Bank Tabungan Negara (Persero) Cabang Yogyakarta.Objekpenelitian ini adalah yang berhubungan dengan PT. Bank Tabungan Negara (Persero) Cabang Yogyakarta.

\section{Metode Pengumpulan Data}

a. Penelitian kepustakaaan (library research)

Yaitu penelitian yang dilaksanskan dengan menggunakan literatur (kepustakaan), baik berupa buku, catatan, maupun laporan hasil penelitian dari penelitian yang terdahulu (M. Iqbal, 2002: 11). Pada Penelitian kepustakaan ini peneliti menggunakan Standar Akuntansi Keuangan (SAK) per 1 September 2007 yang dikeluarkan oleh Ikantan Akuntan Indonesia (IAI) sebagai acuan untuk membahas teori yang mendasari pembahasan masalah dan analisis data dalam penelitian ini, serta menelaah penelitian ini.

b. Penelitian lapangan (field research)

Suatu metode penelitian dengan tujuan langsung di lapangan untuk memperoleh data yang dibutuhkan dalam tehnik pengumpulan data.

1) Wawancara

Wawancara merupakan mengumpulkan data dalam metode survey yang menggunakan pertanyaan secara lisan kepada subjek peneilitian (Indrianto dan Supomo, 2002). Dalam hal ini peneliti melakukan wawancara langsung kepada kepala bagian akuntansi dan kepada kepala bagian kredit PT. Bank Tabungan Negara (Persero) Cabang Yogyakarta untuk mendapatkan data tentang perlakuan akuntansi kredit bermasalah setelah Pernyataan Standar Akuntansi Keuangan (PSAK) No. 31 efektif dicabut.

2) Observasi

Observasi adalah memperoleh data dengan pengamatan secara langsung terhadap obyek yang diteliti (Moh. Nasir, 1999: 212). Peneliti melakukan 
pengamatan secara langsung dengan pemeriksaan fisik yang ada di lapangan lokasi penelitian.

3) Dokumentasi

Dokumentasi adalah mencari data mengenai hal-hal atau variabel yang berupa catatan, transkip, buku, surat kabar, majalah, prasasti, notulen, rapat, lengger, agenda dan sebagainya (Suharsimi, 2002: 206). metode dokumentasi ini untuk memperoleh data tentang profil perusahaan yang berisi gambaran umum perusahaan, visi, misi, struktur organisasi dan laporan keuangan.

\section{Metode Analisis Data}

Metode analisis data yang dilakukan dalam penelitian ini adalah metode analisis deskriptif kualitatif. Metode mengacu pada transformasi dari data-data mentah ke dalam suatu bentuk yang mudah dimengerti dan diterjemahkanya itu dengan mendeskripsikan respons atau hasil dari survey atau temuan di lapangan (GunawanWibisono,2003: 134). Setelah diterjemahkan kemudian dapat diambil kesimpulan dari hasil penelitian serta rekomendasi yang dapat diberikan oleh peneliti. Adapun analisisnya adalah sebagai berikut:

a. Menganalisis perlakuan akuntansi kredit bermasalah pada PT. Bank Tabungan Negara (Persero) sebelum Standar Akuntansi Keuangan No. 31 revisi 2000 tentang Akuntansi Perbankan efektif dicabut pada tanggal 1 Januari 2010.

b. Menganalisis perlakuan akuntansi kredit bermasalah pada PT. Bank Tabungan Negara (Persero) setelah Standar Akuntansi Keuangan No. 31 revisi 2000 tentang Akuntansi Perbankan efektif dicabut pada tanggal 1 Januari 2010.

c. Menganalisis kesesuain perlakuan akuntansi kredit bermasalah pada PT. Bank Tabungan Negara (Persero) setelah Pernyataan Standar Akuntansi Keuangan No. 31 revisi 2000 efektif dicabut pada tanggal 1 Januari 2010 dengan PSAK No. 50 (revisi 2010), PSAK No. 55 (revisi 2011) dan PSAK No.60.

d. Peneliti menarik suatu kesimpulan dan memberikan saran-saran.

\section{HASIL PENELITIAN DAN PEMBAHASAN}

Setelah efektif dicabutnya PSAK No. 31 tentang Akuntansi Perbankan pada tanggal 1 Januari 2010, PT. Bank Tabungan Negara (Persero) Tbk. dalam perlakuan akuntansi untuk instrumen keuangan yaitu aset, ekuitas dan liabilitas menerapkan PSAK No. 55 (Revisi 2006) tentang Pengakuan dan Pengukuran Instrumen Keuangan dan PSAK No. 50 (Revisi 2006) tentang Penyajian dan Pengungkapan Instrumen Keuangan. Penerapan 
PSAK No. 55 (Revisi 2006) dan PSAK No. 50 (Revisi 2006) ini mengacu pada International Accounting Standard (IAS) 39 mengenai Recognition and Measurement of Financial Instrument dan IAS 32 mengenai Presentation and Disclosures of Financial Instruments. Penggunaan PSAK No. 50 (Revisi 2006) dan PSAK No. 55 (Revisi 2006) ini hanya berlaku hingga akhir tahun 2011.

Terhitung sejak tanggal 1 Januari 2012 PT. Bank Tabungan Negara (Persero) Tbk. mulai menerapakan PSAK No. 55 (Revisi 2011) tentang pengakuan dan pengukuran instrumen keuangan, PSAK No. 50 (Revisi 2010) tentang pengungkapan instrumen keuangan dan PSAK No. 60 tentang penyajian instrumen keuangansebagai pengganti dari PSAK No. 55 (Revisi 2006) dan PSAK No. 50 (Revisi 2006).

\section{Perlakuan Akuntansi Kredit Bermasalah setelah PSAK No. 31 Efektif Dicabut}

\section{a. Pengakuan Kredit Bermasalah (Nonperforming Loan)}

PT. Bank Tabungan Negara (Persero) Tbk. mengakui kredit bermasalah ketika pembayaran angsuran pokok dan bunganya telah lewat dari 90 hari.Kredit bermasalah dalam penyajian laporan keuangan merupakan bagian dari komponen kredit yang diberikan.Kredit yang diberikan pada awalnya diukur pada nilai wajar ditambah dengan biaya transaksi yang dapat diatribusikan secara langsung dan biaya tambahan untuk memperoleh aset keuangan tersebut.Setelah pengakuan awal diukur pada biaya perolehan diamortisasi menggunakan metode suku bunga efektif dikurangi dengan penyisihan kerugian penurunan nilai. Pernyataan tersebut sesuai dengan PSAK No. 55 (Revisi 2011) Instrumen Keuangan: Pengakuan dan Pengukuran yang menyatakan pada saat pengakuan awal aset keuangan atau kewajiban keuangan, entitas mengukur pada nilai wajarnya. Dalam hal aset keuangan atau kewajiban keuangan tidak diukur pada nilai wajar melalui laporan laba rugi, nilai wajar tersebut ditambah dengan biaya transaksi yang dapat diatribusikan secara langsung dengan perolehan atau penerbitan aset keuangan atau kewajiban keuangan tersebut.Setelah pengakuan awal pinjaman atau kredit yang diberikan diukur dengan pada biaya perolehan diamortisasi dengan menggunakan metode suku bunga efektif.

\section{b. Pengukuran Kredit Bermasalah (Nonperforming Loan)}

Kredit bermasalah pada PT. Bank Tabungan Negara (Persero) Tbk. merupakan komponen dari kredit yang diberikan yang mengalami penurunan nilai sehingga terjadi keterlambatan pembayaran atau sama sekali tidak ada pembayaran. Penurunan nilai atas kredit yang diberikan dicatat pada biaya 
perolehan diamortisasi kemudian jumlah kerugian tersebut diukur sebagai selisih antara nilai tercatat aset dengan nilai kini estimasi arus kas masa depan (tidak termasuk kerugian kredit di masa depan yang belum terjadi) yang didiskontokan menggunakan suku bunga efektif dari aset yang dihitung pada saat pengakuan awal. Nilai aset tersebut dikurangi baik secara langsung maupun menggunakan pos cadangan. Pengukuran tentang kredit bermasalah pada PT. Bank Tabungan Negara (Persero) Tbk tersebut telah sesuai dengan PSAKNo. 55 (Revisi 2011) tentang pengakuan dan pengukuran instrumrn keuangan paragraf 70 .

\section{c. Penyajian Kredit Bermasalah (Nonperforming Loan)}

Penyajian kredit bermasalah (NPL) pada laporan keuangan disajikan di neraca. Kredit bermasalah disajikan di neraca sebagai komponen dari aktiva dengan nama rekening kredit yang diberikan setelah dikurangi penyisihan kerugian penurunan nilai. Penyajian kredit bermasalah atau instrumen yang tergolong dalam aset keuangan tidak diatur dalam PSAK No. 50 (revisi 2010).PSAK No. 50 (revisi 2010) hanya mengatur tentang penyajian kewajiban dan ekuitas.

\section{d. Pengungkapan Kredit Bermasalah (Nonperforming Loan)}

Pengukuran tentang kredit bermasalah, beserta metode dan kebijakan akuntansi yang digunakan oleh PT. Bank Tabungan Negara (Persero) diungkapkan dalam catatan atas laporan keuangan. Kredit bermasalah diungkapkan dengan nilai wajar pada catatan atas laporan keuangan PT. Bank Tabungan Negara (Persero) Tbk. PT. Bank Tabungan Negara (Persero) Tbk. dalam mengungkapkan kredit bermasalah teah sesuai dengan PSAK No. 60 dimana PT. Bank Tabungan Negara (Persero) Tbk. telah mengungkapkan nilai tercatat kredit bermasalah yang merupakan komponen dari kredit yang diberikan dan mengungkapkan kebijakan akuntansi yang digunakan oleh PT. Bank Tabungan Negara (Persero) Tbk. seperti pengakuan dan pengukuran terhadap kredit bermasalah.

\section{Perlakuan Akuntansi Pendapatan Bunga setelah PSAK No. 31 Efekif Dicabut}

\section{a. Pengakuan Pendapatan Bunga}

Pendapatan bunga pada PT. Bank Tabungan Negara (Persero) Tbk. tidak lagi diakui pada saat bunga tersebut diterima (berbasis kas) namun diakui pada laporan laporan laba rugi dengan menggunakan metode suku bunga efektif.Pada saat menghitung suku bunga efektif, bank mengestimasi arus kas di masa datang dengan mempertimbangkan seluruh persyaratan kontraktual dalam instrumen keuangan tersebut, tetapi tidak mempertimbangkan kerugian kredit di masa 
mendatang. Perhitungan ini mencakup seluruh komisi, provisi, dan bentuk lain yang diterima oleh para pihak dalam kontrak yang merupakan bagian tidak terpisahkan dari suku bunga efektif.

Untuk aset keuangan atau kelompok aset keuangan serupa telah diturunkan nilainya sebagai akibat kerugian penurunan nilai, maka pendapatan bunga yang diperoleh setelahnya diakui berdasarkan suku bunga yang digunakan untuk mendiskontokan arus kas masa datang dalam menghitung kerugian penurunan nilai.Pengakuan ini sesuai dengan PSAK No.55 (revisi 2011) dimana pendapatan dan beban bunga diakui pada laporan laba rugi dengan menggunakan metode suku bunga efektif. Pengakuan untuk pendapatan bunga yang setelah pengakuan mengalami penurunan nilai juga sesuai dengan PA 109 PSAK No.55 (revisi 2011) dimana setelah aset keuangan atau kelompok aset keuangan yang serupa telah dihapusbukukan akibat kerugian penurunan nilai, maka pendapatan bunga diakui menggunakan tingkat bunga yang digunakan untuk mendiskontokan arus kas masa depan untuk tujuan mengukur rugi penurunan nilai.

\section{b. Pengukuran Pendapatan Bunga}

Setelah dicabutnya PSAK No. 31 tentang Akuntansi Perbankan, pengukuran pendapatanpada PT. Bank Tabungan Negara (Persero) Tbk. tidak lagi diukur dengan menggunakan biaya historis melainkan dengan nilai wajar imbalan yang dapat diterima.Jika arus masuk dari kas atau setara kas ditangguhkan, maka nilai wajar dari imbalan tersebut mungkin kurang dari jumlah nominal kas yang diterima atau dapat diterima.Penerimaan antara nilai wajar dengan jumlah nominal dari imbalan tersebut diakui sebagai pendapatan bunga.Dengan demikian PT. Bank Tabungan Negara (Persero) Tbk. dalam pengukuran pendapatan bunga telah sesuai dengan PSAK No. 55 (revisi 2011) dimana dalam pengukuran aset maupun liabilitas lebih menekankan dengan menggunakan nilai wajar.

\section{c. Penyajian Pendapatan Bunga}

Penyajian pendapatan bunga pada laporan keuangan disajikan di laporan laba rugi.Pendapatan bunga yang disajikan dalam laporan laba rugi merupakan pendapatan bunga dari kredit yang digolongkan performing (lancar dan dalam perhatian khusus).Sedangkan untuk pendapatan bunga yang berasal dari kredit dengan golongan nonperforming (kurang lancar, diragukan dan macet) di sajikan di neraca sebagai estimasi kerugian komitmen dan kontinjensi. 


\section{JURNAL NOMINAL / VOLUME II NOMOR I / TAHUN 2013}

\section{d. Pengungkapan Pendapatan Bunga}

Pengungkapan atas pendapatan bunga diungkapkan pada laporan laba rugi dan dalam catatan atas laporan keuangan.Bank mengungkapkan metode akuntansi yang digunakan dalam pendapatan bunga yaitu metode suku bunga efektif.Bank dalam catatan atas laporan keuangan mengungkapkan jumlah pendapatan bunga secara lebih detail. Pendapatan bunga tersebut berasal dari kredit yang diberikan, obligasi pemerintah, efek-efek, penempatan pada bank lain dan giro pada Bank Indonesia. Untuk pendapatan bunga yang digolongkan nonperforming bank mengungkapkan pendapatan bunga dalam penyelesaian di catatan atas laporan keuangan.

Pengungkapan pendapatan bunga pada PT. Bank Tabungan Negara (Persero) Tbk. telah sesuai dengan PSAK No.60 dimana bank mengungkapkan kebijakan dan metode akuntansi yang digunakan, termasuk kriteria pengakuan dan dasar pengukuran yang diterapkan oleh PT. Bank Tabungan Negara (Persero) Tbk.

\section{Perlakuan Penyisihan Kerugian Penurunan Nilai setelah PSAK No. 31 Efektif Dicabut}

PT. Bank Tabungan Negara (Persero) Tbk menentukan penyisihan kerugian penuruan nilai kredit secara kolektif dengan mengacu pada pembentukan penyisihan umum dan penyisihan khusus sesuai dengan ketentuan Bank Indonesia mengenai kualitas aset bank umum.Penyisihan kolektif untuk kredit yang dikelompokkan sebagai dalam perhatian khusus, kurang lancar, diragukan dan macet dihitung setelah dikurangi dengan nilai agunan yang diperkenankan sesuai dengan ketentuan Bank Indonesia.

Perhitungan penyisihan kerugian penurunan nilai berdasarkan nilai tercatat (biaya perolehan amortisasi). Kerugian penurunan nilai atas aset keuangan yang dicatat pada biaya perolehan diamortisasi diukur sebesar selisih antara nilai tercatat aset keuangan dengan nilai kini estimasi arus kas masa datang yang didiskonto menggunakan suku bunga efektif awal dari aset keuangan tersebut. Untuk kredit yang diberikan maka tingkat diskonto yang digunakan untuk mengukur setiap kerugian peurunan nilai adalah suku bunga efektif yang berlaku yang ditetapkan dalam kontrak.

Pendapatan bunga atas aset keuangan yang mengalami penurunan nilai tetap diakui atas dasar suku bunga yang digunakan untuk mendiskonto arus kas masa datang dalam pengukuran kerugian penuruan nilai.Jika persyaratan kredit yang diberikan dimodifikasi karena debitur atau penerbit mengalami kesulitan keuangan, maka 
penurunan nilai diukur dengan suku bunga efektif yang digunakan sebelum persyaratan diubah.

Perlakuan penyisihan kerugian penurunan nilai pada PT. Bank Tabungan Negara (Persero) Tbk. sudah sesuai dengan PSAK No.55 (revisi 2011) dimana perhitungan penyisihan kerugian penurunan nilai berdasarkan nilai tercatat menggunakan biaya perolehan amortisasi dan untuk pendapatan bunga atas aset keuangan yang mengalami penurunan nilai tetap diakui atas dasar suku bunga yang digunakan untuk mendiskonto arus kas masa datang dalam pengukuran kerugian penuruan nilai.

\section{Perlakuan Restrukturisasi Kredit setelah PSAK No. 31 Efektif Dicabut.}

Sejak tanggal 1 januari 2010 saat persyaratan kredit telah dinegosiasi ulang atau dimodifikasi (kredit restrukturisasi), penurunan nilai yang ada diukur dengan menggunakan suku bunga efektif awal yang digunakan sebelum persyaratan diubah dan kredit tidak lagi diperhitungkan sebagai menunggak. Pernyataan tersebut sesuai dengan paragraf 70 PSAK No. 55 (revisi 2011) dimana penurunan nilai atas pinjaman yang diberikan diukur dengan suku bunga efektif awal dari aset tersebut yaitu suku bunga efektif yang dihitung pada saat pengakuan awal.

Dalam melakukan restrukturisasi kredit manajemen secara berkelanjutan mereview kredit yang dinegosiasi ulang untuk meyakinkan terpenuhinya seluruh kriteria dan pembayaran di masa depan. Kredit terus menjadi subjek penilaian penururan nilai individual atau kolektif, dihitung dengan menggunakan suku bunga efektif awal.

\section{Penghapusbukuan Kredit setelah PSAK No. 31 Efektif Dicabut.}

Setelah dicabutnya PSAK No. 31 tentang Akuntansi Perbankan, kredit dihapusbukukan pada PT. Bank Tabungan Negara (Persero) Tbk ketika tidak terdapat prospek yang realistis mengenai pengembalian pinjaman atau hubungan normal antara bank dan debitur telah berakhir.Kredit yang tidak dapat dilunasi tersebut dihapusbukukan dengan mendebit penyisihan kerugian.Penerimaan atas kredit yang telah dihapusbukukan sebelumnya, dikreditkan ke dalam penyisihan kerugian kredit di neraca.

Penghapusbukuan terhadap kredit macet pada PT. Bank Tabungan Negara sesuai dengan penyesuaian PSAK No. 55 (Revisi 2011) tentang penghentian pengakuan terhadap pinjaman yang diberikan atau aset keuangan lain yang diahapusbukukan. Kredit yang tidak dapat dilunasi dihapusbukukan dengan mendebit penyisihan 
kerugian penurunan nilai.Penerimaan kemudian atas kredit yang telah dihapusbukukan sebelumnya, jika pada periode berjalan dikreditkan ke dalam akun penyisihan kerugian penurunan nilai atas kredit yang diberikan di laporan posisi keuangan, sedangkan jika setelah tanggal laporan posisi keuangan dikreditkan sebagai pendapatan operasional lainnya.

\section{E. PENUTUP}

\section{Kesimpulan}

Setelah dicabutnya PSAK No. 31 tentang Akuntansi Perbankan PT. Bank Tabungan Negara (Persero) mulai tanggal 1 Januari 2012 dalam menyajikan aset keuangan dan kewajiban menerapkan PSAK No. 50 (Revisi 2010) tentang Penyajian Instrumen Keuangan, PSAK No. 55 (Revisi 2011) tentang Pengakuan dan Pengukuran Instrumen Keuangan dan PSAK No. 60 tentang Pengungkapan Instrumen Keuangan. Ketiga standar tersebut menggantikan PSAK No. 55 (Revisi 2006) dan PSAK No. 50 (Revisi 2006).Ketiga standar tersebut juga telah sesuai dengan International Financial Reporting System (IFRS) yang sebelumya telah diterapkan oleh perbankan internasional.Praktik perlakuan kredit bermasalah dan pendapatan bunga pada PT. Bank Tabungan Negara (Persero) Tbk. telah sesuai dengan PSAK No. 55 (revisi 2011) dan PSAK No. 60 (revisi 2010).Perlakuan untuk penyisihan kerugian penurunan nilai, restrukturisasi kredit dan penghapusbukuan kredit sudah sesuai dengan PSAK No. 55 (revisi 2011).Khusus untuk penyajian kredit bermasalah dan pendapatan bunga tidak diatur dalam PSAK No.50 (revisi 2010) karena PSAK tersebut hanya mengatur penyajian ekuitas dan liabiitas.

\section{Saran}

a. Praktik perlakuan akuntansi kredit bermasalah yang telah sesuai dengan PSAK No. 55 (Revisi 2011) dan PSAK No.60 (Revisi 2010) diharapkan terus konsisten untuk diterapkan supaya informasi yang dihasilkan memiliki daya banding yang tinggi.

b. Dalam penyajian dan pengungkapan pendapatan bunga yang berasal dari golongan nonperforming (kurang lancar, diragukan dan macet) yang disajikan di neraca sebagai estimasi kerugian komitmen dan kontinjensi sebaiknya PT. Bank Tabungan Negara (Persero) Tbk. menyajikan dan mengungkapkan secara lebih rinci berapa pendapatan bunga yang diterima dari kredit yang digolongkan kurang lancar, diragukan dan macet. 


\section{F. DAFTAR PUSTAKA}

Andi Jayanti. (2012). Perlakuan Akuntansi Kredit Bermasalah (Nonperforming Loan) Kesesuaiannya Sebelum dan Sesudah Pernyataan Standar Akuntansi Keuangan No. 31 efektif dicabut pada PT. Bank Negara Indonesia.Skripsi.Jurusan Akuntansi pada Fakultas Ekonomi Universitas Hasanudin, Makasar.

Ema Dlaudatul W. (2009).Analisis Manajemen Kredit Guna Menekan Terjadinya Kredit Macet (Studi pada Koperasi "Usaha Tama" Ponggok Blitar).Skripsi.Jurusan Manajemen pada Fakultas Ekonomi Universitas Islam Negeri, Malang.

Gunawan Wibisono. (2003). Riset Bisnis. Jakarta: PT. Gramedia Pustaka Utama.

Gunawan Zakaria. (2011). Analisis Perlakuan Akuntansi Untuk Kredit Bermasalah (NonPerforming Loan) Sesuai PSAK No. 31 pada PT. Bank Mandiri (Persero) Tbk.Di Unit Regional Credit Recovery Makasar.Skripsi.Jurusan Akuntansi pada Fakultas Ekonomi Universitas Hasanudin, Makasar.

http://www.bi.go.id diakses pada 1 September 2012

http://www.btn.co.id diakses pada 1 September 2012

Ikatan Akuntan Indonesia.(2007). Standar Akuntansi Keuangan. Jakarta: Salemba Empat. Indra Bastian dan Suhardjono.(2006). Akuntansi Perbankan. Jakarta: Salemba Empat Irham Fahmi dan Yovi Lavianti Hadi.(2010). Pengantar Manajemen Perkreditan.Bandung: Alfabeta

Ismail.(2010). Akuntansi Bank.Jakarta : Penerbit Kencana.

Iswi Hariyani. (2010). Restrukturisasi dan Penghapusan Kredit Macet.Jakarta : PT. Elex Media Komputindo.

Kasmir.(2008). Bank dan Lembaga Keuangan Lainnya. Jakarta: PT. Raja Grafindo Persada.

. (2010). Manajemen Perbankan. Jakarta: PT. Raja Grafindo Persada.

Lukman Dendawijaya. (2003). Manajemen Perbankan. Jakarta: Ghalia Indonesia.

Moh.Nasir.(1999). Metodologi Penelitian. Jakarta: Ghalia Indonesia.

Mudrajad Kuncoro. (2003). Metode Riset untuk Bisnis dan Ekonomi. Jakarta: Erlangga.

M. Iqbal Hasan. (2002). Pokok-Pokok Materi Metodologi Penelitian \& Aplikasinya.Bogor: Ghalia Indonesia.

Lili M. Sadeli. (2006). Dasar-Dasar Akuntansi. Jakarta: PT Bumi Aksara.

Nur Indrianto dan Bambang Supomo.(2002). Metode Penelitian Bisnis. Yogyakarta: BPFE.

Rudianto.(2009). Pengantar Akuntansi. Jakarta: Erlangga. 
Siswanto Sutojo. (1997). Menangani Kredit Bermasalah Konsep, Teknik, dan Kasus. Jakarta: PT. Gramedia.

Sony Warsono, dkk. (2010). Akuntansi UMKM Ternyata Mudah Dipahami dan Dipraktikkan. Yogyakarta: Asgard Chapter.

Suharsimi Arikunto. (2002). Prosedur Penelitian Suatu Pendekatan Praktek edisi Revisi. Jakarta: PT. Rineka Cipta.

S. Munawir. (2002). Akuntansi Keuangan dan Manajemen. Yogyakarta: BPFE.

Teguh Pudjo Mulyono. (2007). Manajemen Perkreditan bagi Bank Komersil. Yogyakarta: BPFE. 